\title{
EMMANUEL LÉVINAS AND STRUCTURALISM
}

SÍNTESE - O estruturalismo alcançou seu zênite de influência no pensamento francês nos anos 60 e 70 do século XX, quando Lévinas escreveu os seus livros mais importantes. Gostaria, portanto, de examinar sua concepção das implicações filosóficas desta corrente teorético-metodológica, cujo impacto nas sciences humaines quase não deixou nenhum pensador francês indiferente na época. Lévinas acusou o estruturalismo de não passar de uma ilusão, na medida em que sua espontaneidade subjetiva faz com que impulsos e instintos sejam descritos como valores da razão prática. Todavia, apesar da divergência entre Lévinas, para quem a ciência deve estar ao serviço da ética, e Lévi-Strauss, que concebia a ética no melhor dos casos como resultado da pesquisa científica e não como seu fim, ambos pensadores embasaram sua ética na mesma premissa respeitar a alteridade do Outro, de cada pessoa, cada sociedade e cada cultura. A crítica de Lévinas não visava a refutação do estruturalismo mas suas premissas teóricas. Se elas pudessem ser ratificadas, alguém poderia justificar a metodologia estruturalista. Portanto, a palavra-chave aqui é "se". Sua crítica não é nenhuma negação absoluta. Sua principal crítica foi a de que o estruturalismo era uma teoria científica que não deixava nenhum lugar para a ética; portanto, Lévinas também considerava o estruturalismo uma ameaça ao judaísmo, onde a ética ocupa um importante lugar. No início do século XX, Rosenzweig - assim como Lévinas no seu fim - buscou propor uma saída da concepção de totalidade porque não deixava lugar adequado para o estatuto do ser humano como sujeito. Para Rosenzweig, tratava-se antes de mais nada de uma revolta contra a filosofia idealista de
ABSTRACT - Structuralism reached the peak of its influence in French thought in the sixties and seventies of the $20^{\text {th }}$ century when Lévinas wrote his most important books. Therefore I want to examine his contention with the philosophical implications of this theoreticalmethodological current to whose impact on "les sciences humaines" almost no French thinker remained indifferent at the time. Lévinas accused structuralism that according to it subjective spontaneity is no more than an illusion by which impulses and instincts are described as values of practical reason. However, notwithstanding the divergence between Lévinas, according to whom science must serve ethics, and Lévi-Strauss, according to whom ethics is at most a result of scientific research and not its end, both established their ethics on the same assumption: to respect the otherness of the other, of every person, every society, every culture. Lévinas' criticism did not aim at refuting structuralism but at wrestling with its theoretical assumptions. If they were possible of ratification, one might justify structuralist methodology. So the keyword is "if". His critique is no absolute denial. His main critique was that structuralism was a scientific theory that left no place for ethics; therefore he also considered structuralism to be a danger to Judaism where ethics occupies an important place. Rosenzweig in the beginning of the $20^{\text {th }}$ century as well as Lévinas at its end endeavored to propose an outlet frm the conception of totality because it did not leave any adequate place for man's status as a subject. For Rosenzweig that had been first of

* Universidade de Haifa, Israel.

\begin{tabular}{|l|l|l|l|l|l|}
\hline VERITAS & Porto Alegre & v. 51 & n. 2 & Junho 2006 & p. 61-68 \\
\hline
\end{tabular}


Hegel, enquanto que para Lévinas compreendia uma crítica do estruturalismo que dava primazia a estruturas inconscientes sobre a subjetividade humana. Apenas esta pode servir de base para uma ética que fosse o propósito maior de sua filosofia

PALAVRAS-CHAVE - Estruturalismo. Filosofia Francesa. Lévinas. Lévi-Strauss. Rosenzweig. all a revolt against Hegel's idealistic philosophy, while for Lévinas it comprised a critique of structuralism that awarded priority to unconscious structures over human subjectivity. Only the latter can serve as a basis for ethics which was the chief goal of his philosophy.

KEY WORDS - Structuralism. French Philosophy. Lévinas. Lévi-Strauss. Rosenzweig.

Structuralism reached the peak of its influence in French thought in the sixties and seventies of the $20^{\text {th }}$ century when Lévinas wrote his most important books. Therefore I want to examine his contention with the philosophical implications of this theoretical-methodological current to whose impact on "les sciences humaines" almost no French thinker remained indifferent at the time. Structuralism distinguished itself by its methodological uniqueness but also represented an epistemological conception that stressed pure theoretical knowledge. It mistrusted any inclination to underscore the free will of the human subject. This was characteristic especially of those disciplines that dealt with man $^{1}$ as its main subjectmatter and strove to dismiss subjectivity and values from scientific knowledge. Lévinas accused structuralism that according to it subjective spontaneity is no more than an illusion by which impulses and instincts are described as values of practical reason. Rather surprisingly Lévinas linked this critique also with an attack on Spinoza because he presented the desired as valuable instead of the value as desirable. ${ }^{2}$ He had in mind Spinoza's assertion "that we do not endeavor, will, seek after or desire because we judge a thing to be good. On the contrary, we judge a thing to be good because we endeavor, will, seek after and desire it."3 This view led, according to Lévinas, to the subjugation of axiology to desires and drives which did not leave any place for the transcendence of human subjectivity. Creative comprehension turns into something objective which is based on sole logical relations; everything is conceived as structures of an all-encompassing system. According to structuralism and contrary to Kant theoretical reason reigns supreme. ${ }^{4}$

In the very same years that Lévinas elaborated his ethics of the Other, Claude Lévi-Strauss developed his structuralist anthropology which emphasized that one ought not consider so-called "primitive" or "savage" cultures as inferior to "our" western civilisation, but to conceive of them as others and to respect this otherness. It is unnecessary to examine in this paper whether and to which degree

The concept "man" in this essay has no gender connotation but means "human", like the German word Mensch

"Ideology and Idealism", The Levinas Reader, ed. by Sean Hand. Oxford and Cambridge: Basil Blackwell, 1989

3 Spinoza, The Ethics, Pt. III, prop. 9, Scholium.

4 Levinas, op. cit., pps. 239-240. 
Lévinas' conept of the other was perhaps also influenced by Lévi-Strauss or vice versa. Lévinas arrived at his ethical conclusions from metaphysical inquiries while Lévi-Strauss came to his ethical statements from ethnological research and considered them as scientific conclusions. Yet, notwithstanding the divergence between Lévinas, according to whom science must serve ethics, and Lévi-Strauss, according to whom ethics is at most a result of scientific research and not its end, both established their ethics on the same assumption: to respect the otherness of the other, of every person, every society, every culture. Lévinas mentioned LéviStrauss and Structuralism on several occasions, e.g. when he connected "our national literatures" with the folklorisms of "Savage Thought". ${ }^{5}$ He noted, however, that he never became attached to structuralism, despite his admiration of Lévi-Strauss' speculative power that presented itself as scientific empiricism. ${ }^{6}$

Lévinas did not write any special essays on Structuralism, but he also did not restrict himself to mere sporadic responses. He performed a thorough analysis of several philosophical assumptions of Structuralism, in order to confront them with his own philosophical views. His criticism did not aim at refuting structuralism but wrestled with some of its theoretical assumptions. If they were possible of ratification, one might justify structuralist methodology. So the keyword is "if". His critique is no absolute denial. His main critical reaction to Structuralism one can find in Autrement qu'être ou au-delà de l'essence. ' So what were those structuralist assumptions or presuppositions that aroused Lévinas' resentment? They did not so much consist in a disagreement with certain thinkers or books, but in a refutation of structuralism as a pretentious scientific current. He was less suspicious of its methodological aspects than of its theoretical and philosophical pretensions and implications. Lévinas' critique was turned against the tendency of generalization and totalization, but he did not hesitate to employ from time to timesome kind of structuralist hermeneutics, e.g. in his Talmudic lectures. He also took avail quite often of the distinction between diachronic and synchronic which pervaded structuralist research since de Saussure and was one of its distinctive features. When he spoke about the "being" (être) of "beings" (étants), he presupposed the presence or possible presence of the "beings", which obviously implicated a synchronic approach. He agreed that simultaneous relations can be investigated most advantageously by structuralist methodology. But on the whole Lévinas denied the synchronic method of structuralism because it ignored the streaming of time and because it tried to establish a spacial system whose components have no before or after. ${ }^{8}$ This is quite surprising because Jewish traditional thought emphasized that "there is no earlier or later in the Torah".

Levinas, "Von der Ethik zur Exegese”, Parabel: Levinas. Giessen: Focus-Verlag 1990, p. 15.

Interview to Nouvelles Litteraires, August 1982, quoted by Salomon Malka, Lire Levinas. Paris: Ed. du Cerf 1984, p. 42.

La Haye: Martinus Nijhoff, 1974.

"Ideology and Idealism", op. cit., pps. 240-241.

9 That was the last of the 32 'Midot' (hermeneutical rules) of the Talmudic Sage Rabbi Eliezer ben Jossi Haglili ( $2^{\text {nd }}$ century a.d.) 
Lévinas referred very rarely to the important distinction of de Saussure between "language" (langue) and "speech" (parole) which became one of the main methodological paradigms of structuralism. He appreciated several thoughts of Michel Foucault, the most philosophical thinker among the structuralists and post-structuralists. Like Foucault his goal was less the research of the historical events themselves but their manifestation in written language (archives etc.). Lévinas underscored, certainly also under the influence of the Jewish distinction between the oral Torah and the written Torah, between spontaneous expressions (speech, utterances) and their permanent contents. These contents may remind one of what Foucault characterized as "archivist features" of the "discourse"; they alone are, according to Foucault, of true scientific signification. Perhaps one can detect in Lévinas' distinction between the oral and the written Torah also a certain echo of de Saussure's distinction between "speech" and "language" which we may rediscover also in Lévinas' distinction between "Dire" (saying) and "Dit" (said).

In this connection one can discover some interesting influence of Lévinas on Derrida: De Saussure emphasized the distinction between language and speech; Foucault, and in his wake Lévinas, stressed the distinction between speech and written texts, and Derrida highlighted the priority of writing ("écriture") to speech. However, Derrida did not come to the issues of speech and writing that occupied a very important place in his thought, from Foucault but, among others, from none other than Lévinas. But these structuralist traces in Lévinas' thought were blurred by his caustic critique of structuralism as clashing with his conception of ethics and the humanities. His critique derived from three main arguments:

I. Structuralism was a scientific theory which left no place for the subject. The same critique was raised also by the French philosopher Paul Ricoeur. Lévinas defined this structuralist position as "théorisme". Thought becomes anonymous; language replaces the speaker and is conceived as a formal system of signs. This contradicts the personalism which is characteristic of Lévinas' thought. Man and God are persons, subjects; on this point he does not make any concessions. The structuralists disregarded man as a subject - Foucault spoke about the "death of man" and L. Althusser about "theoretical anti-humanism", J. Lacan underestimated the human person in his idiosyncratic version of psychoanalysis, and even Lévi-Strauss did so to a certain degree when he described man as a member of a system of structures, unbeknown to him. As against them Lévinas stressed the humanist message of man's relation to the other ("autrui") which drew its inspiration also from Jewish sources. Instead of such objective structuralist trends Lévinas underscored the subjective notion of "non-indifférence" to the other man in his ethics. 
Like Ricoeur Lévinas appreciated Lévi-Strauss' work, but although he employed some structuralist methodology in his Talmudic lectures, he stated explicitly that it seems inapplicable to the Talmud. The reference of the Talmud to the Torah is very different from the "bricolage" in "Savage Thought". ${ }^{10}$ There is, however, a certain lapse in this statement, because the Talmud belongs to a historical epoch while what LéviStrauss characterized as "savage thought" pertained to a pre-historic age which had not yet acquired the art of writing. Although the Jewish tradition refers to the Talmud as the "oral Tora", as against the Torah which is known as the "written Torah", all the Talmudic tractates, including their interpretations, were fully written texts. Lévinas therefore interpreted Lévi-Strauss' concept of "savage thought" incorrectly. His rhetorical question whether one can compare Einstein's scientific intellect with "savage thought", ${ }^{11}$ missed the point. Lévi-Strauss did not deal with exceptional geniuses, but asserted that the mental and logical capacities of "savages" are not inferior to those of western "cultured" persons. He rejected L. Lévy-Bruhl's assumption of "pre-logical" or "primitive" mentality. By the way, Lévinas wrote a rather sympathetic article on the philosophical implications of Levy-Bruhl's view. ${ }^{12}$ Yet Lévi-Strauss' ethical implications are closer to Lévinas' ethics than he thought (vide supra).

II. Foucault very often used indefinite expressions like "on" (which has no exact English counterpart, perhaps "somebody") and "il y a" ("there is") that do not refer to any special subject. ${ }^{13}$ According to Lévinas these expressions imply that anonymous forces fulfill the same role which religion accorded to God and humanism to Man. An utterance such as "il pleut" ("it rains") contradicts the traditional religious belief of Judaism that it is God who brings down rain. Lévinas asserted that on or il y a, notwithstanding the important place of ther latter term in Lévinas' philosophy, cannot express ethical responsibility. There also is no true passage from structuralist "théorisme" to ethics. On this point there is at first sight a paradoxical accord between structuralist thinkers on the one hand and Lévinas on the other. The first excluded ethics from structuralist theory on account of its allegedly non-scientific nature, while Lévinas rejected structuralist theory because it excluded ethics from scientific thought. Therefore he considered structuralism to be a danger to Judaism where ethics occupies a very important place.

Modern atheism is not merely negation of God. It is the absolute indifference of Tristes Tropiques. I think that it is the most atheistic book, written in our time, the absolutely disoriented and disorienting book. It is a menace to Judaism as well as to the Hegelian and sociological vision of history... In France, Judaism ... is troubled by three Jews, by three grand oeuvres: by Eric Weil, by Raymond Aron and by Lévi-Strauss. ${ }^{14}$

10 Quatre lectures talmudiques. Paris: Ed. de Minuit 1968, p. 19. "Bricolage" - "tinkering" - was a favorite term of Lévi-Strauss' anthropological research.

Francois Poirié, Emmanuel Lévinas: Qui êtes-vous?. Lyon: La Manufacture 1987, p. 131

"Levy-Bruhl et la philosophie contemporaine", Entre Nous. Paris: Grasset 1991, pps. 49-63.

Already Heidegger did so with the German word "man", but mainly in order to explain the tendency to avoid thoughts on death.

14 Difficile Liberté. Paris: Albin Michel, 1963 et 1976, p. 280. 
This severe accusation of one of Lévi-Strauss' most beautiful books, imbibed with humanism, that regards the other man - in this case the "wild" Indians in the jungles of Brasil who are at first sight estranged to our western cultural heritage as intellectually equal to us, is incomprehensible and inacceptable. Perhaps this unjust evaluation was caused by Lévinas' annoyance that these three Jews, outstanding personages in the intellectual life of France, did not show any interest in their Jewish heritage. Although on several occasions Lévi-Strauss and Lévinas expressed their mutual admiration, on the philosophical plane they remained uncompromising adversaries.

III. Structuralism considers contents to be secondary to the formal relations that compose the scientific structures. As against that, in the phenomenology of Husserl (which had also been a source of inspiration for Lévi-Strauss), in Heidegger's philosophy and in existentialist thought which all three served as points of departure for Lévinas' philosophy, the contents were the decisive element, although Heidegger's philosophy remained indifferent to ethics which aroused Lévinas' strong critique.. While structuralist methodology leans mainly on a formalist basis, Lévinas endeavors to arrive at "de-formalization".

It is not surprising that Jacques Derrida, in his first great essay on Lévinas, ${ }^{15}$ did not wrestle with him in the spirit of structuralism but in the spirit of the intellectual tradition of western thought whose origin was Greek philosophy. Also Lévinas when he criticized the Greek tradition in favor of the Hebrew tradition, employed Greek terms. According to Derrida this ought indeed to be so. Therefore he defended, in "Violence and Metaphysics", the "Greek" Husserl and Heidegger against Lévinas' objections. He rejected several ideas that were in the centre of Lévinas' thought on these matters: the preference of ethics to ontology, the concept of the radical Other. Derrida based his critique of Lévinas' metaphysics on the concept of "common sense", not in the prevalent connotation of Anglo-Saxon philosophy but in the spirit of phenomenology which served as a common denominator of the beginnings of the philosophizing of both of them.

In the past most philosophers were convinced that consciousness reaches truth by way of thought, but Hegel already dissociated himself from that view and put into question Descartes' Cogito. Likewise modern philosophy is suspicious of supposedly immediate constituents of consciousness. This gave birth to that depersonalization which Lévinas denounced in structuralist theory. Living man, man as a conscious subject, disappeared, as it were, behind an abstract system of structures, conceived by formal-mathematical methods. Not man thinks the structures, but the structures think themselves. In this manner Lévi-Strauss asserted: "We are not, therefore, claiming to show how men think the myths, but rather how the myths think themselves out in men and without men's knowledge."16

\footnotetext{
15 J. Derrida, "Violence et métaphysique: Essai sur la Pensée d’Emmanuel Lévinas", L’Ecriture et la Différence. Paris: Ed. du Seuil 1967, pp. 117-228.

6 C. Lévi-Strauss, Le Cru et le Cuit, Paris: Plon 1964, p. 20.
} 
According to the structuralist, human subjectivity is no more than an illusion. Even the most thoughtful scholars or philosophers are guided ultimately by unconscious cognitive interests; their thought reflects what Lévi-Strauss called "the collective unconscious". Non-personal theory suppresses praxis. These theoretical implications of structuralism were repudiated by Lévinas.

Unconscious influences and motives disguise or conceal man's true image, but they cannot suspend his ineffability as man which is embodied in man's "unegoistical non-interestedness". ${ }^{17}$ This is man's sanctity. Availing himself of the metaphysics of contradictions which he was always very fond of, according to which the same and the other are identical (an idea which he will disclaim later), Lévinas asserted: "Paradoxalement, c'est en tant qu'aliénus - étranger et autre que l'homme n'est plus aliéné." ${ }^{18}$ Thus he tried to lay the foundations for a new humanism which he defined - this was also the title of his book of 1972 - humanism of the other man (this analysis does not necessarily conform to the chronological order of Lévinas' and Derrida's books). The chief innovation in Lévinas' concept of humanism was manifested by his passage from ontological studies to ethics. He repudiated the exclusively ontological dimension in Heidegger's philosophy which left no place for ethics. Man must exert oneself, in order to transcend beyond (au-delà) his given ontological status by creating a relation to the other, namely by a real contact. Here one can detect undoubtedly some affinity to ideas of Buber and Rosenzweig, although he criticized their conception of similarity between the I and the other and stressed their dissimilarity by giving priority to the other over the I; he also disapproved of their dialogical conception of the Godhead that clashed with his view of God's absolute transcendence which he expressed by the neologism "illéité". However, like Rosenzweig who employed the language of the "old thinking" of Hegelian idealism, in order to achieve his "new thinking" ("Das neue Denken"), so did Lévinas when he discarded ontology by availing himself of its terminology.

When he discussed, e.g., the concept of truth, one can distinguish also some indirect traces of structuralist concepts. Concealing truth, i. e. hiding the truth of beings (êtres), is not merely an optical matter, namely that they are not revealed to the eye. Beings are endowed with some kind of "co-présence" one against another; their mutual relations are embodied in a system of significations whose truthfulness is manifested by their structures. However, when these beings are conceived outside their structural relations, they are concealed by a certain shadow. Revealing their structure makes possible to elicit the intelligibility and signification that cannot be discovered, as long as their components are conceived separately. Then they have no more than the meaning which language bestows on them. Therefore one can distinguish between things that are separate intelligibles from the point of view of their subject-matter and the intelligibility of the structural

\footnotetext{
17 Joelle Hansel, "After you - The Idea of Sanctity in the Philosophy of Lévinas", Daat - A journal of Jewish philosophy \&Kabbalah, 30, 1993, pp. 5-12.

18 Autrement qy'être ou au-delà de l'essence. La Haye: Martinus Nijhoff 1974, p. 76
} 
system itself. ${ }^{19}$ From this angle also subjectivity is subordinated to structural arrangements. It can be defined as rational theoretical consciousness, what we designate as "esprit", briefly "l'intelligibilité signifie, tout autant que la manifestation, l'arrangement en système où signifient les étants" ${ }^{20}$ It is, however, quite difficult to understand what Lévinas had in mind in this passage.

Many terms that several decades ago fulfilled an important role in contemporary French philosophy - "destruction", "deconstruction", "unsaying" (dédire), "rupture" (coupure), "transcendence", "différence", "différance", "résistance" etc. - indicate some negative connotation, and even at some verbal violence. Moreover, the prefix "de" reigns, as it were, supreme: deconstruction, decentering, disappearance, dissemination (the title of one of Derrida's most importnt books), demythisation, demythologization (the chief concept of R. Bultmann's theology), demystification (Lévinas), discontinuity, difference, differance (Derrida) and so on. All these words, most of which we encounter in Lévinas' writings, and still more in Derrida's, reflect the recoil from abstract totalities. They express an atmosphere of instability, an all-pervading amorphous milieu. In modern Jewish thought this recoil from totalization was expressed by Franz Rosenzweig; it left its strong impact on Lévinas. It is, however, important to note that Rosenzweig in the beginning of the $20^{\text {th }}$ century as well as Lévinas at its end endeavored to propose an outlet frm the conception of totality which did not leave an adequate place for man's status as a subject (vide supra). For Rosenzweig that had been first of all a revolt against Hegel's idealistic philosophy, while for Lévinas it also comprised a critique of structuralism that awarded priority to unconscious structures over human subjectivity. Only the latter can serve as a basis for ethics which was the chief goal of his philosophy.

${ }_{20}^{19}$ E. Lévinas, Dieu, la Mort et le Temps. Paris: Bernard Grasset 1993, p. 169. Ibid. 